\title{
Must We Release All Sinners Because of Our Sins? Clemency Power in Shakespeare's Measure for Measure
}

\author{
Rinat Kitai-Sangero \\ Carmel Academic Center and College of Law and Business, Ramat Gan, Israel
}

\begin{abstract}
The paper examines the concepts of justice and mercy in Shakespeare's play Measure for Measure. As opposed to the strict meaning of the term "Measure for Measure", analysis of the play demonstrates that it endorses for various reasons the ideas of mercy and clemency, and the conception that every person is entitled to and is capable of redemption.
\end{abstract}

Keywords: retribution, clemency, mercy, Measure for Measure

The jury, passing on the prisoner's life, May in the sworn twelve have a thief or two Guiltier than him they try... -H. C. Hart The Works of Shakespeare: Measure for Measure (1925)

\section{Introduction}

Clemency is an old Anglo-American institution. ${ }^{2}$ Grounds for granting executive clemency, however, are controversial. $^{3}$ Many arguments are raised against appeals to mercy (as opposed to justice) ${ }^{4}$ even within the framework of clemency. ${ }^{5}$ Some scholars hold that clemency should be granted only in cases of actual innocence

\footnotetext{
* Acknowledgements: I am grateful to Boaz Sangero, A. M. Goldstein, and the participants of the International Congress of Humanities and Social Sciences Research held in Paris in 2012, the 10th Annual International Conference on Law of ATINER (Athens Institute for Education and Research) and 7th Global Conference: Forgiveness for their useful comments.

Rinat Kitai-Sangero, Professor of Law, College of Law and Business, Ramat Gan, Israel.

${ }^{1}$ H. C. Hart (Ed.), The Works of Shakespeare: Measure for Measure act 2, sc. 1, at 27-28 (2nd ed., 1925).

${ }^{2}$ Herrera v. Collins, 506 U.S. 390, 411-412 (1993).

${ }^{3}$ Mark Strasser, The Limits of the Clemency Power on Pardons, Retributivists, and the United States Constitution, 41 Brandeis L.J. 85, 87 (2002).

${ }^{4}$ See, e.g., Jeffrie G. Murphy, Mercy and Legal Justice 162, 167-168, in Jeffrie G. Murphy \& Jean hampton, Forgiveness and Mercy (1988); Heidi M. Hurd, The Morality of Mercy, 4 Ohio St. J. Crim. L. 389, 392 (2007); Dan Markel, Against Mercy, 88 Minn. L. Rev. 1421, 1478 (2004); Theodore Eisenberg \& Stephen P. Garvey, Capital Jury: The Merciful Capital Juror, 2 Ohio St. J. Crim. L. 165, 168 (2004); Stephen P. Garvey, Is It Wrong to Commute Death Row? Retribution, Atonement, and Mercy, 82 N. C. L. Rev. 1319, 1324-1325 (2004); Eric L. Muller, The Virtue of Mercy in Criminal Sentencing, 24 Seton Hall L. Rev. 288, 288 (1993).

${ }^{5}$ Kathleen Dean Moore, Pardons: Justice, Mercy and the Public Interest 129 (1989); Kathleen Dean Moore, Pardon for Good and Sufficient Reasons, 27 U. Rich. L. Rev. 281, 284-285 (1993); Eisenberg \& Garvey, supra note 4, at 171 (stating that "mercy-givers can fairly be expected to give reasons for giving mercy"). See also Daniel T. Kobil, The Quality of Mercy Strained: Wresting the Pardoning Power from the King, 69 Tex. L. Rev. 569, 573-574 (1991).
} 
or failure of due process. ${ }^{6}$ Others hold that the wide discretionary power of clemency should be maintained. ${ }^{7}$ In light of the steady decline in the exercise of clemency in the last few decades in the United States, ${ }^{8}$ Shakespeare's play Measure for Measure may help us stand on the complexity of the relevant considerations for exercising the clemency power, and support the extension of mercy in clemency decisions. After presenting the synopsis of the play, the article examines in regard to each offender in the play whether his clemency is justified and addresses possible considerations for the clemency decision.

\section{Synopsis of the Play}

Vincentio, the Duke of Vienna, realizes that his laxity in enforcing the rules has brought about a crisis in regard to obeying laws. Recognizing his personal failure to enforce royal laws, he entrusts powers to a deputy, Angelo. Remaining in Vienna under the guise of a friar instead of leaving for Poland as he had announced, the Duke plans to examine "the terms for common justice.",

Unmarried intercourse is prohibited in Vienna. Angelo conducts a policy of rigorous and even draconian enforcement of this offense. The first offender he judges is Claudio, who has impregnated Juliet, to whom he is legally betrothed; however, no religious ceremony had yet taken place because of the matter of Juliet's dowry. Angelo makes Claudio an example and sentences him to death.

Isabella, Claudio's sister, who is about to enter a nunnery, is summoned by Lucio, a friend of Claudio, to try to persuade Angelo to reduce her brother's punishment. She appeals to Angelo for mercy, but Angelo denies her application. However, Angelo, probably impressed by her beauty and passionate speech, succumbs to his own sexual desires and asks her to return the next day. In their second encounter, he offers to pardon Claudio if Isabella sleeps with him. Furthermore, he threatens that if she disagrees to his demand, he will not just execute her brother but also torture him. Isabella, though, is not ready to consider the offer and chooses her virginity and chastity over saving her brother's life. She angrily rejects Claudio's pleas to accept Angelo's offer.

As a friar in disguise, the Duke pulls the strings. After overhearing the conversation between Claudio and Isabella in prison, he suggests to Isabella a bed-trick: Mariana, Angelo’s former fiancé, to whom he had broken his promise to marry because of the loss of her dowry at sea (together with her brother), will go to Angelo's bed in Isabella's place. When this occurs, Angelo believes that Isabella has kept her part in the agreement; nevertheless, out of fear of revenge ${ }^{10}$ or out of fear of the discovery of his crime, ${ }^{11}$ he breaks his promise to pardon Claudio and orders Claudio's prompt execution.

The Duke frustrates the order by persuading the Provost to substitute Ragozine, a pirate who had died in prison of disease, for Claudio's head, after Barnardine who had been sentenced to death for murder refused to be executed on the specific day because of his drunken state. To increase Isabella's anger toward Angelo, the Duke

\footnotetext{
${ }^{6}$ Mentioned by Jonathan Harris \& Lothlorien Redmond, Executive Clemency: The Lethal Absence of Hope, 3 Crim. L. Brief 2, 7 (2007).

7 Harris \& Redmond, supra note 6, at 2; Mary-Beth Moylan \& Linda E. Carter, Clemency in California Capital Cases, 14 Berkeley J. Crim. L. 37, 97 (2009).

${ }^{8}$ On this decline see: Harris \& Redmond, supra note 6, at 6; Kobil, supra note 5, at 602; Victoria J. Palacios, Faith in the Fantasy: the Supreme Court's Reliance on Commutation to Ensure Justice in Death Penalty Cases, 49 Vand. L. Rev. 311, 347-349 (1996); P. S. Ruckman, Preparing the Pardon Power for the 21st Century, 12 St. Thomas L. J. 446 (2016).

9 Supra note 1 , act 1 , sc. 1 , at 4 .

10 Richard A. Posner, Law and Literature 114 (1998); Amy Ross, Vienna Then and Now: The Impact of Shakespeare's Measure for Measure on The Twenty-First Century Legal Profession, 46 S. D. L. Rev. 781, 795 (2001).

${ }^{11}$ Isaac Asimov, Asimov's Guide to Shakespeare, Volume I, 645 (1970).
} 
as friar tells her that Claudio was executed and that she should bring Angelo's crimes to the Duke's attention when the latter returns and reclaims his authority.

Isabella, indeed, calls for a public trial of Angelo upon the Duke's return to town, accusing the former of extortion and breach of promise and demanding justice. The Duke, pretending not to believe her, accuses her, in turn, of madness and perjury. Then Mariana partly corroborates Isabella's testimony, saying that Angelo had actually slept with her and not with Isabella. Angelo denies the accusations against him.

The turning point of the trial is the Duke's revelation that he actually had stayed in Vienna in disguise. Angelo's guilt is clearly exposed, and the only mercy he requests is an immediate death. The Duke agrees, declaring "an Angelo for Claudio, death for death"; however, he orders Angelo to marry Mariana before being executed. At that point, Mariana begs for Angelo's life and asks Isabella to join her plea of mercy. Isabella agrees and kneels beside Mariana even though she believes that Angelo has executed her brother.

After Mariana and Isabella ask the Duke not to impose the death penalty on Angelo, the Duke begins to issue pardons. Angelo is pardoned and is compelled only to marry Mariana. Claudio is pardoned and is going to marry Juliet, the woman he loves. Surprisingly, the tough murderer, Barnardine, who has expressed no repentance, is also pardoned. Only one person in the play is not completely pardoned although the Duke in this case commutes his previous sentence of hanging and whipping. This is Lucio, who had slandered the Duke in front of the "friar," saying, inter alia, that the Duke's laxity in enforcing the laws stemmed from his own sexual misbehavior. Lucio is to be imprisoned and is also compelled to marry the whore whom he had begot with child. In the end, the Duke proposes marriage to Isabella. She does not respond, but we may assume she accepts his offer.

The article examines now the question of whether the Duke has good reasons for issuing the pardons.

\section{Claudio}

Claudio has received justice rather than mercy; his harsh punishment extremely outweighs the seriousness of his crime. ${ }^{12}$ Although no formal marriage ceremony has taken place, Claudio and Juliet see themselves as married. ${ }^{13}$ Claudio declares that "she is fast my wife." ${ }^{14}$ Civil law too regards Claudio and Juliet as married. ${ }^{15}$ Contemporary social norms refer to premarital sex of this type with understanding. ${ }^{16}$ Even in Shakespeare's time premarital sex was common. ${ }^{17}$ The law prohibiting unmarried intercourse had not been enforced in Vienna for many years. ${ }^{18}$ Concern for the spread of sexual diseases did not exist in Claudio’s case; Juliet is not a whore in a brothel. Actually, it is hard to think of a case of unmarried intercourse with more mitigating circumstances. ${ }^{19}$ Undoubtedly, Angelo should have taken all these considerations into account. ${ }^{20}$

\footnotetext{
12 Kenji Yoshino, On Empathy in Judgment (Measure for Measure), 57 ClEV. ST. L. REv. 683, 687 (2009); Daniel J. Kornstein, Kill All the Lawyers?: Shakespeare’s Legal Appeal 51 (1994); Bernadette Meyler, “Our Cities Institutions” and the Institution of the Common Law, 22 Yale J.L. \& Human. 443, 454 (2010).

13 Yoshino, supra note 12, at 687.

14 Supra note 1, act 1, sc. 2, at 15.

15 O. Hood Phillips, Shakespeare and the lawyers 58 (1972).

${ }^{16}$ Andrew Majeske, Equity's Absence: The Extremity of Claudio's Prosecution and Barnardine's Pardon in Shakespeare's Measure for Measure, 21 Law \& Literature 169, 171 (2009).

${ }^{17}$ Louise Halper, Measure for Measure: Law, Prerogative, Subversion, 13 Cardozo Stud. L. \& Lit. 221, 237 (2001).

18 Supra note 1, act 1, sc. 3, at 19. (The Duke states: "We have strict statutes and most biting laws...which for this fourteen years we have let slip...”). See also Yoshino, supra note 12, at 688; Ernest Schanzer, The Problem Plays of Shakespeare 116 (1963).

${ }_{19}$ Phillips, supra note 15, at 58.

20 Ross, supra note 10, at 805 (citing act 2, sc. 1).
} 
Angelo claims that he is required to follow the rule of law, saying to Isabella: "it is the law, not I, condemns your brother". ${ }^{21}$ The law, though, did not compel the sentence of death in this case. The fact that the trial of Pompey and Froth, the bawds, ended before Escalus with only warnings ${ }^{22}$ teaches that the death sentence for sexual offenses was not mandatory and that Angelo could easily have imposed a far less severe decree. Angelo simply needed to choose an appropriate punishment from among the spectrum of sentences available to him. ${ }^{23}$ Claudio's punishment was disproportionate to the offense. ${ }^{24}$ Imposing the death penalty for a single act of unmarried intercourse in a relatively tolerant society, even disregarding the extenuating circumstances of this case, is contrary to our sense of justice. ${ }^{25}$

Punishment should fit the crime. A defendant has a moral right not to be punished excessively. ${ }^{26}$ An excessive punishment justifies clemency. ${ }^{27}$ The clemency, hence, rectifies the miscarriage of justice caused to Claudio.

\section{Angelo}

Angelo's pardon arouses mixed feelings. Angelo's sin is heavy. He abuses his judicial power for his own purposes by offering Isabella, a novice nun, a corrupt and ugly deal and then seducing her (though, unbeknownst to him, he actually slept with Mariana in her place) ${ }^{28}$ He then breaks his promise to pardon Claudio. Angelo is a cruel person. ${ }^{29}$ His corrupt character has already been revealed in his earlier behavior toward Mariana after the loss of her dowry. ${ }^{30}$ His merciless behavior is further reflected in his warnings to the provost, who tries to speak in favor of Claudio, to mind his own business or lose his job. ${ }^{31}$

The Duke, sentencing Angelo to death, explains: “An Angelo for Claudio, death for death!” ${ }^{32}$ Although Claudio's sentence was not, in fact, carried out, Angelo had imposed the death penalty on him for consensual sex, which was a much lesser offense than the one Angelo himself committed, ${ }^{33}$ as well as being the same offense, unmarried intercourse, for which he had sentenced Claudio to death. ${ }^{34}$ Angelo's hypocrisy is simply amazing. Despite this and despite the seriousness of his crimes, Angelo ultimately bears the least amount of suffering. Claudio had been on death's row, so to speak, for many days prior to his release, while Angelo was pardoned almost immediately after the uncovering of his crimes.

No wonder, then, that some scholars think that one may feel resentment toward Angelo’s pardon and a sense

${ }^{21}$ Supra note 1 , act 2, sc. 2, at 43.

22 Id. act 1, sc. 2, at 36, 38.

${ }^{23}$ Ross, supra note 10, at 805; Note, Shakespeare and the Legal Process: Four Essays, 61 Va. L. Rev. 390, 422-423 (1975).

${ }^{24}$ Yoshino, supra note 12, at 688.

${ }^{25}$ Ross, supra note 10, at 802.

${ }^{26}$ Samuel T. Morison, The Politics of Grace: On the Moral Justification of Executive Clemency, 9 Buff. Crim. L. R. 1, 123 (2005).

27 Kobil, supra note 5, at 627; Joanna M. Huang, Note, Correcting Mandatory Injustice: Judicial Recommendation of Executive Clemency, 60 Duke L. J. 131, 135 (2010).

${ }^{28}$ William T. Braithwaite, Poetry and the Criminal Law: The Idea of Punishment in Shakespeare's Measure for Measure, 13 Loy.

U. Chi. L.J. 791, 812 (1982).

${ }^{29}$ Schanzer, supra note 18, at 84-85.

${ }^{30}$ Id. at 92.

31 Supra note 1, act 2, sc. 2, at 40 .

32 Id. act 5, sc. 1 , at 141 .

33 C. M. A. Mc Cauliff, The Bawd and the Bard: Mercy Tempers Strict Statutory Application in Shakespeare's Measure for Measure, 43 Catholic Law. 81, 113 (2004).

${ }^{34}$ Harriett Hawkins, Measure for Measure 19 (1987). 
that an injustice has been perpetrated. ${ }^{35}$ Can we find justifications for excusing Angelo from punishment?

\section{Emotion Versus Deliberation}

When begging mercy for Angelo, Isabella tries to see things from his perspective: he was carried away by emotions and did not plan the crime in advance. This argument, however, does not hold water. Angelo summoned Isabella to come the next day. Moreover, he had ample time to collect himself from the time he made the proposal to the time of (what seems in his eyes to be) Isabella's consent. According to one scholar, this deliberation "[makes] him the worst kind of criminal in the eyes of the law."36

\section{Lack of Experience and Fitness}

Some scholars try to find points in Anglo's favor in his lack of experience. ${ }^{37}$ However, this is not a case in which the criminality of the deed is unclear. Angelo is certainly well aware of the wrongness of his deeds. ${ }^{38}$

To Angelo's credit, however, we have to remember that he was reluctant to take office in the Duke's absence in the first place, requesting from his superior: "Let there be some more test of my metal, before so noble and so great a figure be stamp'd upon it."39 The Duke not only declines to test Angelo but actually forces him to take the ruler's post. ${ }^{40}$ The Duke might have felt guilty about causing Angelo to fail by forcing him to fulfill a role that did not fit him.

\section{Lack of Harm}

Another point that works to Angelo's credit is that no harm was caused as a result of his misdeeds: Claudio has not lost his life and Isabella's virginity has remained untainted. ${ }^{41}$ Surely, the fact that no harm was done does not testify to Angelo's moral innocence: it was a matter of luck and chance. Many scholars hold that moral blame, and not the cause of harm, should be the primary factor in determining due punishment. ${ }^{42}$ However, taking into account the lack of harm is compatible with moral intuitions, and may be justified in terms of desert. ${ }^{43}$ Angelo indeed has committed the offense of unmarried intercourse (with Mariana), but such an offense does not normally cause any harm to others. ${ }^{44}$

\section{Remorse}

Angelo has also expressed explicit remorse, saying that "I am sorry that such sorrow I procure; And so deep sticks it in my penitent heart that I crave death more willingly than mercy." ${ }^{45}$ His deep repentance may explain his pardon. ${ }^{46}$ True, it was expressed only after realizing that he had been caught almost red-handed. However, the fact that Angelo does not ask for mercy and feels that he deserves death may testify to the sincerity of his

35 Samuel Johnson 42, S.T. Coleridge, 47 in: Shakespeare: Measure for Measure (C.K. Stead ed., 1971).

${ }^{36}$ Ross, supra note 10 , at 798.

37 Mary Lascelles, Shakespeare's Measure for Measure 88 (1953).

38 Supra note 1 , act 2, sc. 2, at 48-49.

${ }^{39}$ Id act 1 , sc. 1 , at 6.

${ }^{40}$ Id.

${ }^{41}$ Majeske, supra note 16, at 177.

42 Stephen P. Garvey, Punishment as Atonement, 48 UCLA L. Rev. 1801, 1825 (1999); Joel Feinberg, Punishment for Failed Attempts: Some Bad but Instructive Arguments Against It, 37 ARIz. L. Rev. 117, 132 (1995).

${ }^{43}$ Joshua Dressler, Reassessing the Theoretical Underpinnings of Accomplice Liability: New Solutions to an Old Problem, 37 Hastings L.J. 91, 105-106 (1985); Paul H. Robinson \& John M. Darley, The Utility of Desert, 91 Nw. U. L. Rev. 453, 491 (1997).

${ }^{44}$ Compare Lawrence v. Texas, 539 U.S. 558 (2003).

45 Supra note 1 , act 5 , sc. 1 , at 144.

${ }^{46}$ Cauliff, supra note 33, at 114. Actually, a claim of remorse has only a little effect on the clemency decision: Moylan \& Carter, supra note 7, at 72 (regarding clemency process in capital cases in California). 
repentance. Some scholars hold that requesting punishment rather than mercy and recognizing that punishment is one's just desert indicates that the repentance is true and honest. ${ }^{47}$ Such a "change of heart" and the wish of the offender to separate his personality from his conduct should bear on one's punishment and mitigate it. ${ }^{48}$

\section{Taking Into Account Human Weaknesses}

Indeed, punishment should take into account common human weaknesses. ${ }^{49}$ In interpersonal relationships, we must forgive the human frailties of others to win love and friendship. ${ }^{50}$ The famous quotation from Matthew says: "Do not judge, so that you may not be judged. For with the judgment you make you will be judged, and the measure you give will be the measure you get." ${ }^{51}$ And that from Luke: "Do not judge and you will not be judged. Do not condemn, and you will not be condemned. Forgive, and you will be forgiven." ${ }^{52}$ Every person is a potential sinner, and no one could venture to throw the first stone. ${ }^{53}$ "For there is not one good man on earth who does what is best and doesn't err., 54

The need for personal forgiveness, though, does not suggest that mercy is desirable in the realm of criminal punishment, especially that which aims to obtain retribution. ${ }^{55}$ When Escalus says, "If any in Vienna be of worth to undergo such ample grace and honour, it is Lord Angelo," ${ }^{, 56}$ he implies that perhaps no person is capable of administering justice in Vienna. However, if no one can judge, then judges should be discharged from duty, and criminal law, in practice, cannot be enforced. ${ }^{57}$ Scholars opine therefore that "the Sermon on the Mount may be a good guide for individuals, but not for states." ${ }^{58}$ There is a distinction between private forgiveness and a judicial duty of determining the punishment. ${ }^{59}$ Human beings' propensity to commit offenses cannot of itself justify impunity and impede any judgment. ${ }^{60}$

Indeed, the judge may have failed or could fail in regard to the same conduct for which he punishes the defendant. Thus, in the affair of Monica Lewinsky, it is quite possible that many of those who condemned the behavior of former President Clinton have themselves had similar or more serious sexual affairs. ${ }^{61}$ In the famous hypothetical case of the Speluncean explorers, cave explorers who found themselves trapped in a cave estimate that they have almost no chance of survival until rescue arrives unless they eat the flesh of one of them, "they claim it is perverse, possibly hypocritical, to punish them for acts that even the best among us might have committed, had we found ourselves in the same predicament." ${ }^{, 62}$ But as various opinions demonstrate and as

\footnotetext{
${ }^{47}$ Paul H. Robinson, The Virtues of Restorative Process, The Vices of “Restorative Justice," 2003 UTAH L. REV. 375, 383. For a discussion of this issue see: Jeffrie G. Murphy, Getting Even: Forgiveness and Its Limits 46-47, 52-53 (2003).

${ }_{48}$ Rinat Kitai-Sangero \& Itay Lipschits, The Place of Repentance in Retributive Sentencing, 7 IJPS 107, 113-117 (2011).

49 Note, supra note 23, at 418.

${ }^{50}$ Hurd, supra note 4, at 416.

51 Matthew: 7:1.

52 Luke 6:37.

53 Yoshino, supra note 12, at 684. See St John 8:3-11.

${ }^{54}$ Ecclesiastes 7:20.

${ }^{55}$ Murphy, supra note 4, at 167-68.

56 Supra note 1 , act 1 , sc. 1 , at 4 .

57 Hawkins, supra note 34, at 72-73.

58 Yoshino, supra note 12, at 687.

59 Schanzer, supra note 18, at 104; Charles L. Griswold, Forgiveness: A Philosophical Exploration 39 (2007).

60 Ross, supra note 10 , at 803.

61 Robert Batey, Kenneth Starr-Among Others—Should Have (Re)read Measure for Measure, 26 Okla. City U.L. Rev. 261, 279 (2001).

62 David L. Shapiro, The Case of the Speluncean Explorers: A Fiftieth Anniversary Symposium, 112 Harv. L. Rev. 1834, 1876 (1999).
} 
Judge Kozinski decided, "That we may feel sympathy for the defendants - that any of us might be in their place but for the grace of God-gives us no authority to ignore the will of the citizens of Newgarth, as embodied in the duly enacted laws." ${ }^{63}$ In the real case of Dudley and Stephens, survivors of a shipwreck who murdered one of their dying friends and ate his flesh, Lord Coleridge declared:

We are often compelled to set up standards we cannot reach ourselves, and to lay down rules which we could not ourselves satisfy. But a man has no right to declare temptation to be an excuse, though he might himself have yielded to it, nor allow compassion for the criminal to change or weaken in any manner the legal definition of the crime. ${ }^{64}$

When Escalus asks Angelo to consider mercy for Claudio and to ask himself whether he might have performed the same offense, Angelo declines mercy, replying: "Tis one thing to be tempted, Escalus, Another thing to fall... You may not so extenuate his offense for I have had such faults; but rather tell me, when I, that censure him, do so offend, let mine own judgment pattern out my death." ${ }^{35}$ Now Angelo proves his readiness to judge himself with the same rigidity he has judged others.

Nevertheless, punishment should reflect the public's feeling of condemnation regarding a specific offense in order to increase compliance with the law. ${ }^{66}$ Laws that are repeatedly violated by ordinary persons teach that they are simply unworkable; they do not reflect the public's sense of justice. Thus, Prohibition failed to convey the message that alcohol consumption was illegitimate. ${ }^{67}$ Likewise, imposing a ban on acceptable sexual behavior is inconsistent with both human nature and the sense of justice, and it creates hypocrisy. ${ }^{68}$ If all the criminals are executed, Pompey, the bawd, suggests, nobody would be left in Vienna within ten years. ${ }^{69}$ Angelo's insistence to strictly enforce the law stems largely from his lack of understanding human nature. ${ }^{70}$

Knowing that a reasonable person might commit the same offense under the same circumstances should enable us to see and perhaps to take the offender's perspective. ${ }^{71}$ Thus, for example, the law makes concessions to human weaknesses through the defense of "heat of passion". 72

According to Aristotle, it is easier to pardon persons when they succumb to desires which are common to all people. ${ }^{73}$ Angelo surrenders completely to his lust. Lust is indeed a dominant factor in people's life. Many people, perhaps even most people, may yield to temptation. We must remember, however, that there are degrees of guilt, and only few would have acted as Angelo did, extorting sex through a bold abuse of his office and-worse?-breaking his promise after achieving what he wanted. ${ }^{74}$ Angelo's crime does not necessarily reflect a common weakness of human beings, and should not be forgiven on the basis of this reason.

${ }^{63}$ Id. at 1877.

64 The Queen v. Dudley \& Stephens, 14 Q.B.D. 273, 288 (1884).

65 Supra note 1, act 2, sc. 1, at 27-28.

66 Robinson \& Darley, supra note 31, at 456.

67 Neal Kumar Katyal, Deterrence’s Difficulty, 95 Mich. L. Rev. 2385, 2452 (1997).

${ }^{68}$ Cauliff, supra note 33, at 86.

69 Supra note 1 , act 2, sc. 1 , at 38.

70 See also Posner, supra note 10, at 118.

71 Griswold, supra note 59, at 82.

72 Joshua Dressler, Rethinking Heat of Passion: A Defense in Search of a Rationale, 73 J. Crim. L. \& Criminology 421, 459 (1982).

73 Aristotle, The Nicomachean Ethics, Book VII, vi at 181 (2004).

${ }^{74}$ C. K. Stead, Introduction in: Shakespeare: Measure for Measure, supra note 35, at 20. 
Despite the seriousness of Angelo's crimes, the Duke wants to teach Angelo tolerance both for the weaknesses of others and for the latter's own weaknesses through mercy. The recognition that he is not the perfect man he deems himself to be teaches Angelo humility and promises a less arrogant person, and an individual more attentive to others in the future. ${ }^{75}$

\section{The Victim's View}

Isabella's begging for mercy is obviously the main immediate reason for the Duke's decision to pardon Angelo. We do not know the main reasons for her agreement to forgive. Probably, she wants to help Mariana to save her husband. Perhaps she does not want the death penalty to be imposed anymore for sex offenses. ${ }^{76}$ It is impressive to see how Isabella has learned to show mercy. After Claudio begs Isabella to accept Angelo’s offer, she concludes that Claudio deserves no mercy, saying: "I'll pray a thousand prayers for thy death, no word to save thee... Thy sin's not accidental, but a trade. Mercy to thee would prove itself a bawd: Tis best that thou diest quickly. ${ }^{, 77}$ Now Isabella is capable of giving mercy even to a foe. ${ }^{78}$ Moreover, she recognizes herself as a human being who is capable of feeling love. ${ }^{79}$

It is quite customary to hear the victim and her family before deciding on clemency. ${ }^{80}$ However, determining the sentencing decision according to the victim's view is problematic. The victim is, only naturally, a prejudiced person, who will find it difficult to evaluate objectively what justice demands in a specific case. ${ }^{81}$ Taking the victim's view into account might violate the principle of equality, which requires that two offenders who committed an identical act under the same circumstances will be treated alike. ${ }^{82}$ The question of whether the victim is vindictive or merciful has actually more to do with "luck.” Moreover, Isabella cannot forgive Angelo on Claudio's behalf. Only the victim has standing to forgive the offender. ${ }^{83}$ The main harm, had Claudio been executed as Angelo planned, was caused to her brother, not to her, and a dead person (as Claudio was presumed to have been), unfortunately, cannot forgive. However, in the reality in which the Duke is the almighty decision-maker and the principle of equal punishment has no meaning, the victim's position could certainly be taken into account and affect the nature and degree of the punishment meted out.

\section{Harm to Innocent Persons}

Another possible consideration for Angelo's pardon is the impact of the punishment on third parties. Mariana loves Angelo. She does not want to take his property and to find another husband, as the Duke suggests.

The question of whether the punisher should take into account harm to innocent third parties is controversial. ${ }^{84}$ Thus, in many cases, imprisonment causes suffering to the guilty person's family, which may be cut off from a loved one and perhaps even from its financial supporter. Separation of parents from their children,

\footnotetext{
75 See also Cauliff, supra note 33, at 115.

${ }^{76}$ Cauliff, supra note 33, at 114.

77 Supra note 1 , act 3 , sc. 1 , at 70 .

78 Yoshino, supra note 12, at 695.

${ }^{79}$ Note, supra note 23, at 417-418.

80 Moylan \& Carter, supra note 7, at 56 ; Harris \& Redmond, supra note 6, at 9 (regarding California).

${ }^{81}$ Michael Moore, Victims and Retribution: A Reply to Professor Fletcher, 3 Buff. Crim. L. Rev. 65, 75-76 (1999).

${ }^{82}$ Id. at 77.

${ }^{83}$ Moore, supra note 5, at 187; GRISwOLD, supra note 59, at 117 (stating that this is the common view and suggesting. id., at $118-119$, to qualify this rule).

${ }^{84}$ Hurd, supra note 4, at 416.
} 
too, is an ordinary and even obvious result of imprisonment. ${ }^{85}$ Extraordinary family responsibilities, however, provide a basis for a downward departure from the Sentencing Guidelines. ${ }^{86}$ The idea of extraordinary family responsibilities does not obviously diminish the offender's degree of culpability. It may even enhance his or her moral culpability because of the lack of responsibility displayed in not taking into account the consequences of the misdeed on one's closest relatives. Mitigation of the punishment because of the harm it may cause others expresses concern for the welfare of innocent third parties. ${ }^{87}$ This policy seems to be justified, not just in a case of extraordinary family responsibilities. After all, it is immoral to show indifference to the needs of others. A utilitarian point of view that considers the needs of the general population would certainly take such harm into account.

\section{Learning a Lesson}

It should also be recalled that Angelo has actually been taught a lesson. He slept with someone he did not choose, just as he wanted to do to Isabella. ${ }^{88}$ He underwent a public trial, and no longer serves as the Duke's deputy. ${ }^{89} \mathrm{He}$ is forced to marry Mariana. Although one might find it hard to understand Mariana's interest in Angelo after his shameful behavior toward her, we can assume that Mariana will make Angelo a better person by teaching him loyalty and grace. ${ }^{90}$ Marriage, after all, is not a bad way to teach one tolerance. In sum, there are reasonable grounds to conclude that justice is served in Angelo's case.

\section{Lucio}

Lucio abandoned his illegitimate son and had testified falsely in order to escape responsibility as a father. He has no limits: he accuses the friar (the disguised Duke) of having slandered the Duke although he himself was the one who said the exact things he attributed to the friar.

Lucio received his main sentence on a different plane than formal punishment: he had to bear the consequences of his promiscuous sexual behavior by marrying Kate Keepdown, the whore, and acknowledging paternity of their 15-month-old son. Lucio looks upon his forced marriage as the harshest punishment: "Marrying a punk ... is pressing to death, whipping, and hanging!"91 Indeed, he feels that his reputation has been seriously violated by this order. ${ }^{92}$ The forced marriage is understandable; the Duke takes care of the child's welfare and wants to prevent a future injustice to the innocent child. ${ }^{93}$ But why did he add to the forced marriage the punishment of imprisonment?

Some scholars view Lucio as a person who needs external constraints. ${ }^{94}$ His was not a one-time failure: he routinely engaged in unmarried intercourse. As a repeat offender, Lucio needs an external penalty and more

\footnotetext{
${ }^{85}$ Karen R. Smith, United States v. Johnson: The Second Circuit Overcomes the Sentencing Guidelines' Myopic View of "Not Ordinarily Relevant” Family Responsibilities of the Criminal Offender, 59 Brooklyn L. Rev. 573, 600 (1993).

86 Id. at 576.

${ }^{87}$ Joseph B. Schimmel, Commutation of the Death Sentence: Florida Steps Back from Justice and Mercy, 20 Fla. St. U. L. Rev. 253, 268 (1992) (regarding decisions of clemency) .

${ }^{88}$ Hawkins, supra note 34, at 44-45.

${ }^{89}$ Cauliff, supra note 33, at 121.

90 Cauliff, supra note 33, at 102-103; Josephine Waters Bennett, Measure for Measure as Royal Entertainment 126 (1966).

91 Supra note 1, act 5, sc. 1, at 146 .

92 Cauliff, supra note 33, at 89.

${ }_{93}$ Id. at 90.

94 Braithwaite, supra note 28, at 813.
} 
deterrence to change his behavior. ${ }^{95}$ Moreover, he did not repent his offense; in fact, he seems to find no wrong in his behavior. Since the likelihood that he has learned his due lesson from his misdeeds is slim, perhaps prison will make him understand the seriousness of his misdeeds. ${ }^{96}$

Despite this, it seems that Lucio was punished too harshly in light of the sweeping pardons that Angelo and Barnardine received. Lucio is not a bad person. He shows real concern for Claudio. It may be that Lucio was severely punished because, although the Duke says that he forgives the slander, he found it difficult in the event to do so. And upon Lucio's complaint about his forced marriage, the Duke replies: "Slandering a prince deserves it." "97 James I, the new King in Shakespeare's time, has treated harshly the offense of slander, especially slander of the King. ${ }^{98}$ People, indeed, tend more easily to forgive acts that do not hurt them personally. ${ }^{99}$

\section{Barnardine}

Barnardine is a murderer. In a case of murder, undoing the past and cancelling the consequences of the misdeed are impossible. A play entitled Measure for Measure leads us prima facie to expect the death penalty for murder. ${ }^{100}$ Still, the murder could have been committed under mitigating circumstances, but we have no indication of them in the play. The pardon is not necessary therefore to correct a miscarriage of justice in terms of a wrongful conviction or a deprivation of due process (unless we believe, as I personally believe, that death penalty is an illegitimate punishment).

A redemptive theory of justice would take rehabilitation into account to reduce the severity of the punishment or to pardon an offender. ${ }^{101}$ This theory was prevalent a few decades ago. ${ }^{102}$ We have no evidence, however, that Barnardine has been rehabilitated while in prison. The facts actually suggest the contrary. Barnardine never repents his crime, ${ }^{103}$ and he seems to be a dangerous person. ${ }^{104}$ The provost, who knew Barnardine well during the murderer's nine years in prison, testifies that he would not show him pity even if he were his brother. ${ }^{105}$ No wonder, then, that some scholars view Barnadine’s pardon as “astonishing.”106

Why, then, Barnardine was pardoned?

It may certainly be the case that the play advocates mercy for all; mercy, it suggests, is simply a good virtue and so may be offered to anyone irrespective of the nature of the misdeeds. ${ }^{107}$ The play is consistent with the message that every person is a candidate for mercy. This view is strengthened by what Isabella articulates to

\footnotetext{
${ }^{95}$ Kim Reynolds, Power and Pleasure: Measure for Measure in: Linda Cookson, Bryan Loughrey, Longman Critical Essays, Measure for Measure 20 (1994); Huang, supra note 27, at 163 (regarding the connection between recidivism and deterrence).

96 Joel Feinberg, Doing and Deserving 100 (1970) (stating generally that "the very walls of his cell condemn him, and his record becomes a stigma”).

${ }^{97}$ Supra note 1 , act 5 , sc. 1 , at 146.

98 Schanzer, supra note 18, at 125.

99 Graham Nicholls, Measure for Measure: Text \& Performance 25 (1986).

100 Majeske, supra note 16, at 177.

101 Margaret Colgate Love, Of Pardons, Politics and Collar Buttons: Reflections on the President's Duty to Be Merciful, 27 Fordham Urb. L.J. 1483, 1491 (2000); Harris \& Redmond, supra note 6, at 7; Molly Clayton, Note, Forgiving the Unforgivable: Reinvigorating the Use of Executive Clemency, 54 B.C.L. REv. 751, 757 (2013).

102 Harris \& Redmond, supra note 6, at 7.

103 Majeske, supra note 16, at 177.

104 Mark Spencer Ellis, What Final Statement? in: Longman Critical Essays, Measure for Measure, supra note 95, at 91.

105 Supra note 1, act 4, sc. 2, at 99.

106 Majeske, supra note 16, at 177.

107 Hawkins, supra note 34, at 78.
} 
Angelo: “No ceremony that to great ones longs, not the king's crown, nor the deputed sword, the marshal's truncheon, nor the judge's robe, become them with one half so good a grace as mercy does." ${ }^{108}$ According to this view, "Barnardine was spared because he is the lost sheep, evidence and symbol of the ultimate extent of the Divine mercy.",109

We should also remember that the Duke was introduced to Barnardine personally, and it is more difficult to be harsh with people you know. ${ }^{110}$

Perhaps the Duke wants to suggest an extreme alternative, that of mercy and pardons, to Angelo's draconian enforcement of the law ${ }^{111}$ in the hope that the future will find a middle way between these two extremes.

The Duke's pardon of the murderer, however, hardly offers guidance in regard to the enforcement of laws in the future. Given that a "governor may commute a sentence at any time for any reason without reference to any standards," 112 Barnardine's clemency might be exactly this kind of case-an arbitrary clemency. However, it may be claimed that Barnardine's clemency expresses the view that imposing the harshest punishment is not useful for society and that it is better to err toward leniency. ${ }^{113}$

Barnardine's pardon is actually a conditional one. ${ }^{114} \mathrm{He}$ is to be supervised by a friar, whose task is to help him become a person of good moral character. The Duke has the power to annex conditions to his clemency. ${ }^{115}$ More optimistically, then, we may see the clemency as respecting Barnardine as a human being who is capable of redemption in tandem with ensuring that he would not repeat his wrongdoing.

\section{Conclusion}

In a play entitled Measure for Measure, we expect that everyone will receive their just deserts. But mercy prevails over (rigid?) justice; "the play ends with a rejection of retributive justice and an affirmation of the doctrine of forgiveness preached in the New Testament." ${ }^{116}$ We see multiple reasons to grant clemency. We find ourselves in an atmosphere of sweeping pardons. Some scholars believe that the message of Shakespeare's play is that mercy and forgiveness are the true achievement of justice. ${ }^{117}$ Leaders must understand the complexity and weaknesses of human beings. ${ }^{118}$ Through his pardons, the Duke conveys the message of moderation and humility for the future.

If we assume that pardons should be built on the platform of justice in terms of retribution, it is difficult to justify Barnardine’s pardon and perhaps Angelo’s pardon. However, Measure for Measure insists, contrary to the

\footnotetext{
108 Supra note 1 , act 2, sc. 2, at 43.

109 Bennett, supra note 90, at 28.

110 Cedric Watts, Why Barnardine? in: Longman Critical Essays, Measure for Measure, supra note 95, at 40.

111 Majeske, supra note 16, at 177-78.

112 Solem v. Helm, 463 U.S. 277, 301 (1983). See also in this regard Kobil, supra note 5, at 578; Sarat Austin \& Hussain Nasser, On Lawful Lawlessness: George Ryan, Executive Clemency, and the Rhetoric of Sparing Life, 56 Stan. L. Rev. 1307, 1324-1325 (2004).

113 Note, supra note 23, at 426.

114 For the possibility of issuing a conditional pardon, see Ex parte Grossman, 267 U.S. 87, 120 (1925).

115 Biddle v. Perovich, 274 U.S. 480, 486 (1927); Schick v. Reed, 419 U.S. 256, 266 (1974); Harris \& Redmond, supra note 6, at 3. On the presidential power to impose conditions see in detail: Leonard B. Boudin, The Presidential Pardons of James R. Hoffa and Richard M. Nixon: Have the Limitations on the Pardon Power Been Exceeded?, 48 U. Colo. L. Rev. 1, 17-21 (1976); Harold J. Krent, Conditioning the President's Conditional Pardon Power, 89 CAL. L. REV. 1665 (2001).

116 Watts, supra note 110, at 51.

117 Mentioned by Michael Jay Willson, A View of Justice in Shakespeare's The Merchant of Venice and Measure for Measure, 70 Notre Dame L. Rev. 695, 707 (1995).

118 Cauliff, supra note 33, at 110.
} 
seeming unbending principle of "an eye for an eye, a tooth for a tooth," that human frailties should be taken into account when meting out punishment and that every person is capable of redemption.

The sweeping pardons allow one to start life anew in Vienna. It is not clear, however, how law will be enforced there in the future. Will the law become a scarecrow again, ${ }^{119}$ or find the golden mean between mercy and rigorousness? Kornstein's conclusion that "law should be enforced, but in moderation" 120 seems too optimistic, but definitely not out of the question.

In tandem with mercy, the Duke also conveys the message of acceptance of responsibility. Every offender is forced to take responsibility for his sexual behavior, which is done through marriage or forced marriage. ${ }^{121}$ Taking responsibility, however, should not necessarily lead to a criminal punishment. After all, marriage is not a bad solution for achieving the societal stability that was violated by sexual misbehavior. ${ }^{122}$ For some persons, it is also not a light punishment. Adoption of the Duke's creativity in imposing punishments and granting clemency in our society might perhaps achieve a healthier society. The trust that the Duke imparts to all his pardonees is contagious. It makes us hope that the sweeping pardons are not a mockery of the criminal justice system, and, moreover, it makes us believe that clemency should be a significant component of the criminal justice system and that the wide power of clemency which takes into account a range of factors in the decision making should remain intact, ${ }^{123}$ and be used more generously.

\section{References}

Aristotle. (2004). The Nicomachean ethics. New York, U.S.: Oxford University Press.

Asimov, I. (1970). Asimov's guide to Shakespeare (Vol. I). New York, U.S.: Doubleday and Company.

Austin, S., \& Nasser, H. (2004). On lawful lawlessness: George Ryan, executive clemency, and the rhetoric of sparing life. Stanford Law Review, 56, 1307-1344.

Batey, R. (2001). Kenneth Starr-Among others—Should have (Re)read Measure for Measure. Oklahoma City University Law Review, 26, 261-306.

Bennett, J. W. (1966). Measure for Measure as royal entertainment. New York, US: Columbia University Press.

Boudin, L. B. (1976). The presidential pardons of James R. Hoffa and Richard M. Nixon: Have the limitations on the pardon power been exceeded?. University of Colorado Law Review, 48, 1-40.

Braithwaite, W. T. (1982). Poetry and the criminal law: The idea of punishment in Shakespeare's Measure for Measure. Loyola University of Chicago Law Journal, 791-816.

Clayton, M. (2013). Forgiving the unforgivable: Reinvigorating the use of executive clemency. Boston College Law Review, 54, 751-788.

Cookson, L., \& Loughrey, B. (1994). Longman critical essays, Measure for Measure. London, UK: Longman Group.

Dressler, J. (1982). Rethinking heat of passion: A defense in search of a rationale. Journal of Criminal Law and Criminology, 73, 421-470.

Dressler, J. (1985). Reassessing the theoretical underpinnings of accomplice liability: New solutions to an old problem. Hastings Law Journal, 37, 91-140.

Eisenberg, T., \& Garvey, S. P. (2004). Capital jury: The merciful capital juror. Ohio State Journal of Criminal Law, 2, $165-194$.

Feinberg, J. (1970). Doing and deserving. Princeton, US: Princeton University Press.

Feinberg, J. (1995). Punishment for failed attempts: Some bad but instructive arguments against it. Arizona Law Review, 37, 117-134.

Garvey, S. P. (1999). Punishment as atonement. UCLA Law Review, 48, 1801-1858.

\footnotetext{
119 As Angelo says, supra note 1, act 2, sc. 1, at 27, "We must not make a scarecrow of the law, sitting it up to fear the birds of prey, and let it keep one shape, till custom make it their perch and not their terror."

${ }_{120}$ Kornstein, supra note 12, at 62. For this point see also SCHANZER, supra note 18, at 114.

121 Cauliff, supra note 33, at 121-122.

122 Cauliff, supra note 33, at 91; see also Bruce King, Coriolanus 73 (1989) (stating that "the three marriages at the end of Measure for Measure formally conclude the play with a feeling of renewal and justice satisfied").

${ }^{123}$ As Justice Rehnquist noted in Ohio Adult Parole Authority v. Woodard, 523 U.S. 272, 280-281 (1998): “the heart of executive clemency is to grant clemency as a matter of grace, thus allowing the executive to consider a wide range of factors not comprehended by earlier judicial proceedings and sentencing determinations”.
} 
Garvey, S. P. (2004). Is it wrong to commute death row? Retribution, atonement, and mercy. North Carolina Law Review, 82, 1319-1343.

Griswold, C. L. (2007). Forgiveness: A philosophical exploration. Cambridge, UK: Cambridge University Press.

Halper, L. (2001). Measure for Measure: Law, prerogative, subversion. Cardozo Studies of Law and Literature, 13, 221-264.

Harris, J., \& Redmond, L. (2007). Executive clemency: The lethal absence of hope. Criminal Law Brief, 3, 2-15.

Hawkins, H. (1987). Measure for measure. Boston, US: Twayne Publishers.

Huang, J. M. (2010). Note, correcting mandatory injustice: Judicial recommendation of executive clemency. Duke Law Journal, 60, 131-166.

Hurd, H. M. (2007). The morality of mercy. Ohio State Journal of Criminal Law, 4, 389-422.

Katyal, N. K. (1997). Deterrence's difficulty. Michigan Law Review, 95, 2385-2476.

King, B. (1989). Coriolanus. London, UK: Palgrave Macmillan Press.

Kitai-Sangero, R., \& Lipschits, I. (2011). The place of repentance in retributive sentencing. International Journal of Punishment and Sentencing, 7, 107-137.

Kobil, D. T. (1991). The quality of mercy strained: Wresting the pardoning power from the king. Texas Law Review, 69, 569-642.

Kornstein, D. J. (1994). Kill all the lawyers?: Shakespeare’s legal appeal. Princeton, US: Princeton University Press.

Krent, H. J. (2001). Conditioning the president's conditional pardon power. California Law Review, 89, 1665-1720.

Lascelles, M. (1953). Shakespeare's Measure for Measure. London: Athlone Press.

Love, M. C. (2000). Of pardons, politics and collar buttons: Reflections on the president's duty to be merciful. Fordham Urban Law Journal, 27, 1483-1514.

Majeske, A. (2009). Equity’s absence: The extremity of Claudio's prosecution and Barnardine’s pardon in Shakespeare's Measure for Measure. Law \& Literature, 21, 169-184.

Markel, D. (2004). Against mercy. Minnesotta Law Review, 88, 1421-1480.

McCauliff, C. M. A. (2004). The bawd and the bard: Mercy tempers strict statutory application in Shakespeare's Measure for Measure. Catholic Lawer, 43, 81-124.

Meyler, B. (2010). "Our cities institutions” and the institution of the common law. Yale Journal of Law and the Humanities, 22, 441-466.

Moore, K. D. (1989). Pardons: Justice, mercy and the public interest. New York, US: Oxford University Press.

Moore, K. D. (1993). Pardon for good and sufficient reasons. University of Richmond Law Review, 27, 281-288.

Moore, M. (1999). Victims and retribution: A reply to Professor Fletcher. Buffalo Criminal Law Review, 3, 65-90.

Morison, S. T. (2005). The politics of grace: On the moral justification of executive clemency. Buffalo Criminal Law Review, 9, $1-138$.

Moylan, M. B., \& Carter, L. E. (2009). Clemency in California capital cases. Berkeley Journal of Criminal Law, 14, 37-104.

Muller, E. L. (1993). The virtue of mercy in criminal sentencing. Seton Hall Law Review, 24, 288-346.

Murphy, J. G. (2003). Getting even: Forgiveness and its limits. New York, US: Oxford University Press.

Murphy, J. G., \& Hampton, J. (1988). Forgiveness and mercy. Cambridge, UK: Cambridge University Press.

Nicholls, G. (1986). Measure for Measure: Text \& performance. London, UK: Palgrave Macmillan Press.

Note. (1975). Shakespeare and the legal process: Four essays. Virginia Law Review, 61, 390-433.

Palacios, V. J. (1996). Faith in the fantasy: The supreme court's reliance on commutation to ensure justice in death penalty cases. Vanderbilt Law Review, 49, 311-372.

Phillips, O. H. (1972/2005). Shakespeare and the lawyers. Abingdon, UK: Routledge.

Posner, R. A. (1998). Law and literature. Cambridge, Massaschussets, US, London, UK: Harvard University Press.

Robinson, P. H. (2003). The virtues of restorative process, the vices of "Restorative justice”. Utah Law Review, 375-388.

Robinson, P. H., \& Darley, J. M. (1997). The utility of desert. North Western University Law Review, 91, 453-499.

Ross. A. (2001). Vienna then and now: The impact of Shakespeare's Measure for Measure on the twenty-first century legal profession. South Dakota Law Review, 46, 781-812.

Ruckman, P. S. (2016). Preparing the pardon power for the 21st century. Saint Thomas Law Journal, 12, 446-482.

Schanzer, E. (1963). The problem plays of Shakespeare. New York, US: Schocken Books.

Schimmel, J. B. (1992). Commutation of the death sentence: Florida steps back from justice and mercy. Florida State University Law Review, 20, 253-282. 